\title{
Effect of cold and hot ambient temperatures on plasma progesterone concentrations in ewes with intact and denervated ovaries containing experimentally maintained corpora lutea
}

\author{
A. G. Wheeler and A. W. Blackshaw \\ Department of Physiology \& Pharmacology, University of Queensland, St Lucia, Queensland 4067. \\ Australia
}

\begin{abstract}
Summary. Twenty ewes in which maintained corpora lutea had been established were subject to 1 of 3 treatments: denervation of the ovaries by freezing, denervation of the ovaries using the chemical 6-hydroxydopamine, or control. The animals were exposed sequentially to normal $\left(24.5^{\circ} \mathrm{C}\right)$, cold $\left(10.7^{\circ} \mathrm{C}\right)$, normal $\left(23.8^{\circ} \mathrm{C}\right)$, hot $\left(39.4^{\circ} \mathrm{C}\right)$ and normal $\left(24 \cdot 6^{\circ} \mathrm{C}\right)$ temperatures, each for 1 week. On the final 3 days of exposure rectal temperatures and heart rates were measured, and on the final day the body weights, respiratory rates, and blood glucose concentrations were measured and a series of 5 blood samples was collected from each ewe for determination of the progesterone concentrations. The progesterone concentration was greatest during the hot period in 8 of the 12 animals, particularly in the ewes with denervated ovaries ( 6 of the 7 animals). This suggests that high ambient temperatures increase progesterone concentrations non-specifically, and that denervated ovaries are more sensitive to the circulating catecholamines that presumably mediate this effect. The progesterone concentrations were lower $(P<0.001)$ in the groups with freezing or chemically denervated ovaries $(2.86$ and $2.73 \mathrm{ng} / \mathrm{ml}$ respectively) than in the control group $(3.38 \mathrm{ng} / \mathrm{ml})$, suggesting that the ovarian innervation plays a physiological role in regulating progesterone secretion.
\end{abstract}

\section{Introduction}

The peripheral blood concentrations of progesterone in the ewe vary with the season (Lamond $e t$ al., 1972; Rhind et al., 1977, 1978; Quirke et al., 1979), increased concentrations being associated with low temperatures (Wheeler \& Barnes, 1983). If this increased progesterone concentration is a direct effect of low temperatures, high temperatures should be expected to induce low progesterone concentrations. A decreased progesterone concentration associated with high environmental temperatures may contribute to the poor lambing performance observed in Merino ewes in inland areas of Australia (Powell, 1976), low progesterone concentrations being associated with increased early embryonic loss (Ashworth et al., 1984). This project was therefore undertaken to examine and quantify the variation in the peripheral progesterone concentration in ewes exposed to high ambient temperatures in controlled environments.

As with other forms of stress, exposure to heat and cold results in a re-adjustment in the tonic discharge of the sympathetic and parasympathetic nervous systems (Selye, 1950). It is well established that the mammalian ovary, including that of the sheep, is richly innervated by the autonomic nervous system (Neilson et al., 1970; Stefenson et al., 1981). It has been shown that adrenergic agonists stimulate progesterone secretion by sheep luteal tissue in vitro (Jordan et al., 1978), and increase the progesterone concentration in the pregnant ewe by Flint et al. (1974). Exposure to high 
temperatures would increase sympathetic tone and therefore induce increased progesterone concentrations. This effect would be increased in animals with denervated ovaries due to denervationhypersensitivity to circulating catecholamines (Cannon \& Rosenblueth, 1949). The possible mediation of the ovarian sympathetic nerve supply in the ambient temperature-progesterone concentration relationship was therefore investigated by determining the variation, if any, in the progesterone concentration with ambient temperature in ewes with denervated ovaries.

\section{Materials and Methods}

Animals. Thirty parous Merino ewes were treated with cloprostenol (125 $\mu \mathrm{g}$; Estrumate: I.C.I. Australia Operations, Melbourne, Victoria) on 25 October to induce the regression of any corpora lutea that might be present. (October is during the anoestrous season for Merino ewes in the southern hemisphere; Kupfer, 1978.) The ewes were injected 7 days later with 500 i.u. PMSG (Folligon; Intervet International B.V., Boxmeer, The Netherlands) and 3 days later with 750 i.u. hCG (Chorulon; Intervet) to stimulate a moderately increased ovulation rate. After 3 days the ewes were laparotomized and the first 20 animals that had responded satisfactorily were selected.

Normal luteal regression was prevented by ligating the uterine branches of the utero-ovarian vein and the tubal venous arcade to prevent luteolysis (Baird \& Land, 1973); the corpora lutea and the peripheral progesterone concentration were thus maintained (Baird et al., 1976) for the duration of the experiment. The corpora lutea were counted and the ewes were randomly allocated to 1 of 4 treatment groups.

Five untreated ewes were monitored to establish the effects of exposure to the various temperatures on the peripheral blood progesterone concentration.

In 5 of the ewes the adrenergic nerves to each of the ovaries were destroyed by injecting, through a 25 -gauge needle, each ovary twice with $0.05 \mathrm{ml}$ of a slow release preparation (Collier et al., 1972) of 6-hydroxydopamine (6-OHDA); a mixture of $2.5 \mathrm{mg}$ ascorbic acid (BDH Chemicals, Port Fairy, Victoria), 0.3 g 6-OHDA (Sigma, St Louis, MO, U.S.A.), 0.375 ml Arlacel A (Sigma), $2.125 \mathrm{ml}$ liquid paraffin $(0.88 \mathrm{~kg} / \mathrm{l}$; E. Merck, Darmstadt, FRG; Art. 7174) and $0.9 \mathrm{~g}$ sodium chloride/l. This regimen delivered $6 \mathrm{mg}$ 6-OHDA to each ovary. 6-OHDA is absorbed by adrenergic fibres via their normal catecholamine-uptake mechanism and kills them (Kostrzewa \& Jacobowitz, 1974). A preliminary experiment (A. G. Wheeler, unpublished observations) had shown that this treatment reduced the catecholamine content of the sheep ovary from 905.4 to $87 \cdot 1 \mathrm{ng} / \mathrm{g}$, indicating that the ovaries had been substantially denervated.

The ovaries were denervated in the third group of 5 ewes by applying a $3.3 \mathrm{~mm}$ diameter stainless-steel probe cooled in liquid nitrogen to $-196^{\circ} \mathrm{C}$ three times for $20 \mathrm{sec}$ each to the vascular pedicle supplying each ovary (Filogamo \& Muti, 1968; Gibson et al., 1984).

All three groups of sheep were housed together in a single pen within a temperature-controlled room under constant lighting ( $8 \mathrm{~h}$ light, $16 \mathrm{~h}$ dark). The experimental treatment began at least 2 weeks after the surgery and consisted of sequential exposure to $24 \cdot 5,10 \cdot 7,23 \cdot 8,39.4$ and $24 \cdot 5^{\circ} \mathrm{C}$ each for 1 week under otherwise constant conditions. Before the experiment began (on the day of laparotomy), and on the first day of each temperature period, the animals were shorn to reduce the fleece length to less than $5 \mathrm{~mm}$ to increase the effect of the various temperature exposures on the ewes (Hopkins et al. 1978). On the last day of each treatment period five 7-ml blood samples were collected by venepuncture at about 16-min intervals from the jugular veins of each ewe into evacuated, heparinized tubes. The effects of the temperature exposures on the animals were evaluated by measuring rectal temperatures (as an indicator of internal abdominal temperatures; Mead \& Bonmarito, 1949) and pulse rates on each of the last 3 days and respiratory rates (a sensitive indicator of thermal stress), body weights and plasma glucose concentrations (as a general indicator of stress) on the last day of exposure to each temperature.

At the conclusion of the experiment the effectiveness of the denervation procedures was checked 
by removing and dividing the ovaries from each ewe, arbitrarily allocating half the ovary for assay of the catecholamine concentrations (Von Euler \& Lishajko, 1961) and half for the assessment of the number of monoamine nerve terminals by fluorescent histochemistry (de la Torre \& Surgeon, 1976).

Progesterone concentrations. The plasma was separated from the blood samples and stored at $-20^{\circ} \mathrm{C}$ until assayed for progesterone.

Plasma samples $(100 \mu \mathrm{l})$, to which $20 \mu$ l ethanol were added, were extracted by vortexing with $2 \mathrm{ml} n$-hexane. The aqueous phase was frozen and the $n$-hexane was tipped into a second tube, dried under nitrogen and the solutes redissolved in phosphate-buffered saline containing gelatin $(0 \cdot 1 \%$ $\mathrm{w} / \mathrm{v})$ and sodium azide $(0 \cdot 1 \% \mathrm{w} / \mathrm{v})$. A measured volume of the standard solution of progesterone (Sigma) in ethanol was similarly evaporated and redissolved in buffer; serial dilutions were made to give a range of known amounts of progesterone. Then $100 \mu \mathrm{l}$ of a 1:2000 dilution of the antiserum and $100 \mu \mathrm{l}$ of a $100000 \mathrm{c.p.m}$./ml (approx.) solution of tritiated progesterone $\left(\left[1,2,6,7-{ }^{3} \mathrm{H}\right]\right.$ progesterone; sp. act. 3.29 TBq/mmol; Amersham Australia, Sydney, NSW) were added and the tubes were incubated at $4^{\circ} \mathrm{C}$ for $3 \mathrm{~h}$ or overnight. The antibody-bound and free steroid were separated by exposure to $1 \mathrm{ml}$ dextran-charcoal mixture $(0.0625$ and $0.625 \%$, w/v, respectively) in phosphategelatin buffer for $15 \mathrm{~min}$ at $4^{\circ} \mathrm{C}$ before centrifugation. The supernatant was tipped into scintillation vials and $2 \mathrm{ml}$ scintillation fluid (toluene containing $0.3 \%(\mathrm{w} / \mathrm{v})$ PPO, $0.03 \%(\mathrm{w} / \mathrm{v})$ POPOP and $4 \%$ $(\mathrm{w} / \mathrm{v})$ acetic acid) were added for determination of the radioactivity. The assay data were computed using a logit-log transformed standard curve.

The progesterone antiserum (No. 334) had cross-reactions of $100 \%$ with progesterone, $27 \%$ with $11 \beta$-hydroxyprogesterone, $6.9 \%$ with 11 -deoxycorticosterone, $5.8 \%$ with corticosterone and $1.4 \%$ with $5 \beta$-pregnane-3,20-dione, and $<1 \%$ with $17 \alpha$-hydroxyprogesterone, 20 $\alpha$ - and 20ß-hydroxy-4-pregnen-3-one, pregnenolone and cortisol. The efficiency of extraction was $85.8 \pm 1.43$ (s.e.m.) $\%(n=59)$. The minimum detectable dose (calculated by reading the mean binding in tubes with no progesterone minus 2.5 times their standard deviation off the standard curve; Dighe \& Hunter, 1974) was $36 \cdot 1 \pm 3.06 \mathrm{pg} /$ tube $(n=48)$. The repeated assay of a pool of sheep peripheral plasma collected during the luteal phase of an oestrous cycle gave a mean value of $2.22 \pm 0.085 \mathrm{ng} / \mathrm{ml}(n=34)$. The repeated assay of plasma from an ovariectomized ewe to which known amounts of progesterone had been added to give samples containing $0,1 \cdot 25,2 \cdot 5,5.0$ and $10 \mathrm{ng} / \mathrm{ml}$ gave data from which a regression line of $y=0.915+0.756 x$ (where $y$ is the assayed progesterone concentration and $x$ the added concentration in $\mathrm{ng} / \mathrm{ml}$ ) and a standard deviation of the regression coefficient of $0.052(t(42)=17.71, P<0.001)$ were calculated (Snedecor \& Cochran, 1967). The intra- and inter-assay coefficients of variation (Dighe \& Hunter, 1974) were 14.25 and $4.53 \%$ respectively.

Glucose concentrations. The concentration of glucose in the fifth plasma sample collected on final day of exposure to each temperature was assayed using an automatic glucose analyser (Yellow Springs Instrument Co., YS1 Model 23AM).

Statistical analyses. The variations in the untransformed peripheral progesterone concentrations and other measures were examined by analysis of variance and the means were compared by using Student's $t$ test (Sokal \& Rohlf, 1981).

\section{Results}

A preliminary assay of one plasma sample from each of the ewes and treatments revealed that in 3 of the ewes the progesterone concentration decreased below $1 \mathrm{ng} / \mathrm{ml}$, indicating that luteal regression had occurred during the experiment. Since the consequent cyclic variation in the progesterone concentration would confuse any temperature effects, the samples from these animals were not considered further. 
Table 1. Pooled responses of the Merino ewes on the final 3 days (rectal temperatures and pulse rates) or the final day (respiratory rates, body weights and plasma glucose concentrations), and air temperatures measured twice daily on the final 3 days, of exposure to various ambient temperatures

\begin{tabular}{|c|c|c|c|c|c|c|}
\hline & $\begin{array}{c}\text { No. of } \\
\text { observations }\end{array}$ & Control & Cold & Control & Hot & Control \\
\hline $\begin{array}{l}\text { Air temp. } \\
\left({ }^{\circ} \mathrm{C}\right)\end{array}$ & 6 & $24.5 \pm 0.36$ & $10.7 \pm 1.03$ & $23.8 \pm 1.01$ & $39.4 \pm 0.8$ & $24 \cdot 6 \pm 0 \cdot 08$ \\
\hline $\begin{array}{l}\text { Rectal temp. } \\
\left({ }^{\circ} \mathrm{C}\right)\end{array}$ & 45 & $39.2 \pm 0.05$ & $38.7 \pm 0.08$ & $39 \cdot 1 \pm 0.04$ & $40.4 \pm 0.06$ & $38.9 \pm 0.03$ \\
\hline $\begin{array}{l}\text { Respiratory } \\
\text { rate }\left(\min ^{-1}\right)\end{array}$ & 15 & $101 \pm 8.7$ & $22 \pm 1 \cdot 2$ & $42 \pm 2 \cdot 9$ & $203 \pm 12 \cdot 6$ & $43 \pm 5 \cdot 8$ \\
\hline $\begin{array}{l}\text { Pulse rate } \\
\left(\mathrm{min}^{-1}\right) \\
\text { Body weight }\end{array}$ & 45 & $88 \pm 2 \cdot 1$ & $82 \pm 1 \cdot 7$ & $84 \pm 2 \cdot 3$ & $76 \pm 1 \cdot 9$ & $73 \pm 1 \cdot 7$ \\
\hline $\begin{array}{l}\text { (kg) } \\
\text { Plasma glucose }\end{array}$ & 15 & $35 \cdot 1 \pm 1 \cdot 20$ & $35 \cdot 7 \pm 1 \cdot 16$ & $36 \cdot 3 \pm 1 \cdot 29$ & $36 \cdot 2 \pm 1 \cdot 24$ & $36 \cdot 0 \pm 1 \cdot 20$ \\
\hline conc. (mM) & 15 & $4 \cdot 7 \pm 0 \cdot 12$ & $4 \cdot 4 \pm 0 \cdot 14$ & $4 \cdot 3 \pm 0 \cdot 17$ & $4.8 \pm 0.11$ & $4.9 \pm 0.13$ \\
\hline
\end{tabular}

Values are mean \pm s.e.m.

Table 2. Mean progesterone concentration $(\mathrm{ng} / \mathrm{ml})$ in the five blood samples collected from each sheep on the final day of exposure to each of the five ambient temperatures

\begin{tabular}{|c|c|c|c|c|c|c|c|c|}
\hline Treatment & $\begin{array}{l}\text { Sheep } \\
\text { no. }\end{array}$ & Control & Cold & Control & Hot & Control & $\begin{array}{c}\text { Mean } \pm \text { s.e.m. } \\
(n=25)\end{array}$ & Significance $\S$ \\
\hline Control & $\begin{array}{r}8 \\
35 \\
38 \\
47 \\
49\end{array}$ & $\begin{array}{l}4 \cdot 52 \\
2 \cdot 47 \\
3 \cdot 39 \\
3 \cdot 70 \\
2 \cdot 74\end{array}$ & $\begin{array}{l}3 \cdot 17 \\
2 \cdot 15 \\
3 \cdot 15 \\
2 \cdot 94 \\
2 \cdot 36\end{array}$ & $\begin{array}{l}4 \cdot 59 * \\
3 \cdot 02 \\
4 \cdot 49 \\
3 \cdot 03 \\
2 \cdot 35\end{array}$ & $\begin{array}{l}4 \cdot 04 \\
3 \cdot 80 \\
3 \cdot 37 \\
5 \cdot 00 \\
2 \cdot 72\end{array}$ & $\begin{array}{l}3 \cdot 87 \\
2 \cdot 75 \\
4 \cdot 37 \\
4 \cdot 27 \\
2 \cdot 18\end{array}$ & $\begin{array}{l}4.04 \pm 0.174 \\
2.84 \pm 0.199 \\
3.75 \pm 0.172 \\
3.79 \pm 0.190 \\
2.47 \pm 0.077\end{array}$ & $\begin{array}{c}P<0.05 \\
\quad \text { ns } \\
P<0.05 \\
P<0.001 \\
\quad \text { ns }\end{array}$ \\
\hline Frozen & $\begin{array}{r}7 \\
34 \\
42\end{array}$ & $\begin{array}{l}4 \cdot 23 \\
1 \cdot 23 \\
2 \cdot 08\end{array}$ & $\begin{array}{l}4.40 \\
1.21 \\
1.65\end{array}$ & $\begin{array}{l}4 \cdot 18 \\
2 \cdot 28 \\
1 \cdot 77\end{array}$ & $\begin{array}{l}\mathbf{5 \cdot 2 8} \\
1 \cdot 87 \\
\mathbf{2 \cdot 4 2}\end{array}$ & $\begin{array}{l}5 \cdot 06 \\
1.51 \\
2 \cdot 07\end{array}$ & $\begin{array}{l}4.63 \pm 0.290 \\
1.62 \pm 0.185 \\
2.00 \pm 0.153\end{array}$ & $\begin{array}{c}\text { ns } \\
P<0.01 \\
\text { ns }\end{array}$ \\
\hline 6-OHDA & $\begin{array}{l}33 \\
39 \\
41 \\
43\end{array}$ & $\begin{array}{l}3 \cdot 74 \\
1 \cdot 85 \\
3 \cdot 24 \\
2 \cdot 24\end{array}$ & $\begin{array}{l}2 \cdot 09 \\
1 \cdot 72 \\
2 \cdot 72 \\
1 \cdot 36\end{array}$ & $\begin{array}{l}2 \cdot 30 \\
1 \cdot 74 \\
3 \cdot 50 \\
2 \cdot 11\end{array}$ & $\begin{array}{l}4 \cdot 14 \\
2 \cdot 67 \\
4 \cdot 90 \\
2 \cdot 35\end{array}$ & $\begin{array}{l}3 \cdot 01 \\
2 \cdot 15 \\
4 \cdot 41 \\
2 \cdot 31\end{array}$ & $\begin{array}{l}3.05 \pm 0.236 \\
2.03 \pm 0.126 \\
3.75 \pm 0.224 \\
2.07 \pm 0.133\end{array}$ & $\begin{array}{c}P<0.05 \\
P<0.05 \\
P<0.05 \\
\text { ns }\end{array}$ \\
\hline
\end{tabular}

${ }^{*}$ The greatest mean for each sheep is in bold print.

§The maximum significance of the variation in the data with the temperature exposure calculated for each ewe using a two-way analysis of variance (d.f.: 4,16 ). ns: not significant, $P>0.05$.

Table 3. The numbers of corpora lutea induced in each ovary before the treatments were applied, and the weights, catecholamine concentrations and fluorescence 'scores' of the ovaries removed at the conclusion of the experiment

\begin{tabular}{lcccc}
\hline \multicolumn{1}{c}{ Treatment } & No. of CL & $\begin{array}{c}\text { Ovarian wt } \\
(\mathrm{g})\end{array}$ & $\begin{array}{c}\text { Catecholamine } \\
\text { content }(\mathrm{ng} / \mathrm{g})\end{array}$ & $\begin{array}{c}\text { Fluorescence } \\
\text { 'score' }\end{array}$ \\
\hline Control $(\mathrm{N}=10)$ & $1 \cdot 2 \pm 0.36$ & $1 \cdot 71 \pm 0.294$ & $1037 \pm 320.8$ & $3.3 \pm 0 \cdot 21$ \\
Frozen $(\mathrm{N}=10)$ & $1 \cdot 1 \pm 0.38$ & $1 \cdot 22 \pm 0.232$ & $436 \pm 133 \cdot 3$ & $1 \cdot 1 \pm 0.43$ \\
6-OHDA $(\mathrm{N}=10)$ & $0.8 \pm 0.25$ & $1.38 \pm 0.279$ & $640 \pm 163 \cdot 1$ & $2 \cdot 1 \pm 0.43$ \\
Total $(\mathrm{N}=30)$ & $1.03 \pm 0 \cdot 27$ & $1.43 \pm 0.155$ & $704 \pm 131 \cdot 8$ & $2 \cdot 2 \pm 0 \cdot 27$ \\
\hline
\end{tabular}

Values are mean \pm s.e.m. 
The ovulatory response to the pretreatment PMSG and hCG resulted in $2.07 \pm 0.30$ corpora lutea per ewe (range 1 to $5, \mathrm{~N}=15$; Table 3 ). This represents a moderate stimulation compared to a mean ovulation rate of 1.09 observed in spontaneously cyclic Merino ewes by Wheeler \& Land (1977). There was no significant variation in the numbers of corpora lutea between the three treatment groups $(F(2,27)=0.389 ; P>0.05)$.

There were no differences between the treatment groups in the rectal temperatures, respiratory rates, pulse rates, body weights and plasma glucose concentrations of the ewes; these data have therefore been pooled and are shown with the mean air temperatures to which the sheep were exposed in Table 1. The exposure to cold and heat succeeded in stressing the sheep in that the rectal temperatures were depressed and elevated respectively, and the respiratory rates decreased and increased respectively (Table 1). The relatively unaffected heart rates, plasma glucose concentrations and body weights indicate that the temperature stresses had not been so severe as to unduly jeopardize the homeostasis of the animals.

The mean progesterone concentrations for each of the 12 ewes with maintained corpora lutea for each temperature exposure are shown in Table 2. For blood samples 1, 2, 3, 4 and 5, the mean \pm s.e.m. (no. of samples) progesterone concentrations were $2 \cdot 82 \pm 0 \cdot 152(60), 2.93 \pm 0 \cdot 159$ (60), $3 \cdot 11 \pm 0 \cdot 178(60), 3 \cdot 11 \pm 0 \cdot 193$ and $2 \cdot 96 \pm 0 \cdot 179(60) \mathrm{ng} / \mathrm{ml}$ respectively. For ovarian treatments control, frozen and 6-OHDA, the mean \pm s.e.m. (no. of samples) progesterone concentrations were $3.38 \pm 0.092(125), 2.68 \pm 0.204(75)$ and $2.73 \pm 0.117(100) \mathrm{ng} / \mathrm{ml}$ respectively. For the $24 \cdot 5,10 \cdot 7,23 \cdot 8,39 \cdot 4$ and $24 \cdot 6^{\circ} \mathrm{C}$ temperature periods the mean \pm s.e.m. (no. of samples) progesterone concentrations were $2.87 \pm 0.167$ (60), $2.41 \pm 0.133(60), 2.95 \pm 0.154$ (60), $3.53 \pm 0 \cdot 174(60)$ and $3 \cdot 18 \pm 0 \cdot 197(60) \mathrm{ng} / \mathrm{ml}$ respectively. An analysis of variance of the complete progesterone data identified significant variations between the sheep $(F(11,278)=39 \cdot 7$; $P<0.001$ ) from a minimum of $1.62 \pm 0.185$ (mean \pm s.e.m.; Ewe 34 ) to $4.63 \pm 0.290 \mathrm{ng} / \mathrm{ml}$ (Ewe $7)$, treatments $(F(2,278)=25 \cdot 5 ; P<0.001)$ with the control animals $(3.38 \pm 0.092)$ greater than the denervated groups (frozen: $2 \cdot 68 \pm 0 \cdot 204$, and 6-OHDA: $2 \cdot 73 \pm 0 \cdot 117 \mathrm{ng} / \mathrm{ml}$ ), and temperatures $(F(4,278)=16.0 ; P<0.001)$ with the hot period greatest $(3.53 \pm 0.174)$ and the cold least $(2.41 \pm 0.133 \mathrm{ng} / \mathrm{ml})$. Analysis of variance of the data within each animal revealed a significant variation $(P<0.05)$ between temperature exposures in 7 of the 12 ewes (Table 2$)$.

The mean weights of the ovaries removed from the control and ovarian denervation groups are shown in Table 3; there was no significant variation between the treatment groups $(F(2,27)=0.871 ; P>0.05)$. The mean ovarian catecholamine concentrations and monoamine fluorescence histochemistry 'scores' (an arbitary assessment of the amount of fluorescence in each section) are also shown in Table 3 . The catecholamine contents did not vary significantly between the treatment groups $(F(2,27)=1.903 ; P>0.05)$. The fluorescence 'scores' did vary significantly $(F(2,27)=9.072 ; P<0.001)$, being less than in the controls in the frozen $(t(18)=4.677$; $P<0.001)$ and 6-OHDA $(t(18)=2.484 ; P<0.05)$ denervated groups.

There was no correlation between the ovarian catecholamine concentration and the monoamine fluorescence 'score' for each ovary $(r(28)=0.23 ; P>0.05)$. Within each ewe there was no correlation between the left and the right ovaries for the catecholamine contents $(r(13)=0 \cdot 34$; $P>0.05)$, while there was for the monoamine fluorescence 'scores' $(r(13)=0.65 ; P<0.01)$. There were no correlations between the overall mean progesterone concentration for each sheep and the mean ovarian catecholamine content $(r(10)=0 \cdot 16 ; P>0 \cdot 05)$ and mean monoamine fluorescence 'score' $(r(10)=0 \cdot 27 ; P>0 \cdot 05)$.

\section{Discussion}

The serial exposure of ewes with maintained corpora lutea to various ambient temperatures resulted in a moderate variation in the peripheral progesterone concentrations. Previously published data describing increased progesterone concentrations in the ewe associated with exposure to 
low temperatures (Lamond et al., 1972; Rhind et al., 1977, 1978; Quirke et al., 1979; Wheeler \& Barnes, 1983) had led us to expect a decreased progesterone concentration when animals were exposed to high temperatures. However, the greatest mean concentration was measured in samples collected during exposure to the higher temperature in 8 of the 12 ewes. For the remaining 4 ewes the greatest progesterone concentration appeared in the various intermediate-temperature periods. The lowest temperature achieved in this experiment $\left(10.7^{\circ} \mathrm{C}\right)$ was greater than that found to be associated with increased progesterone concentrations elsewhere (e.g. Wheeler \& Barnes, 1983), and presumably did not sufficiently stress our animals.

The increased progesterone concentrations associated with high ambient temperatures in the present experiment have been observed in cattle (Stott \& Wiersma, 1973; Rosenberg et al., 1977, 1982). Similarly increased progesterone concentrations have been associated with low environmental temperatures in sheep (Lamond et al., 1972; Rhind et al., 1977; Quirke et al., 1979; Wheeler \& Barnes, 1983), dairy cows (Rosenberg et al., 1982) and Murrah buffalo cows (Rao \& Pandy, 1982). These observations suggest that the progesterone concentration is not directly related simply to the ambient temperature; rather that exposure to any extreme thermal environment, cold or hot, produces an increased progesterone concentration compared to that observed in animals in thermally neutral environments. The mechanism for this response is presumably that exposure to stressful environments produces increased sympathetic tone within the animal (Selye, 1950), and that the increased sympathetic nervous activity and circulating catecholamines stimulate the ovarian luteal cells to secrete increased amounts of progesterone (Condon \& Black, 1976).

A residual season or age variation in the peripheral progesterone concentration generated by persistent corpora lutea would have complicated the interpretation of the results. However, there is no indication of any systematic variation with time in the present data, or over such short periods in the measured peripheral progesterone concentrations in ewes with persistent corpora lutea in an ovary surgically transplanted to the neck (Baird et al., 1976).

The greatest proportion of maximum progesterone concentrations during the hot period was observed in the 6-OHDA-treated ewes (4/4), and the greatest progesterone concentration occurred at this time in $6 / 7$ of the ovarian-denervated ewes compared to $2 / 5$ of the control (innervated) animals. This may be a reflection of the denervated ovary exhibiting the phenomenon of denervation-hypersensitivity to circulating catecholamines (Cannon \& Rosenblueth, 1949).

The observation of considerable ovarian catecholamine concentrations by tissue assay and monoamine fluorescence histochemistry in some ovaries presumably represents the re-growth of the ovarian innervation after the freezing- and 6-OHDA-induced denervation (Jacobowitz \& Laties, 1970; Goding et al., 1971). The assessment of the extents of the ovarian monoamine innervation and the ovarian catecholamine content were made at the end of the experiment between 50 and 53 days after some ovaries had been treated to destroy adrenergic nerves. After such an internal reinnervation of the ovaries had probably started; Gibson et al. (1984) observed the maximum reduction of the ovarian innervation between 2 and 10 days after freezing of the vascular pedicle. This reinnervation presumably accounts for the variable monoamine innervations and catecholamine contents observed. Nevertheless, the treatments used here both resulted in reduced innervations that persisted until the ovaries were removed 50 days after the denervation treatments.

The reduced progesterone concentrations found in the ewes with denervated ovaries suggest that the ovarian nerves play a physiological role in regulating ovarian progesterone secretions. If normal stimulation by adrenergic nerves was lacking, progesterone secretion from denervated ovaries would not be as stimulated as from innervated ovaries (Godkin et al., 1977).

The results therefore suggest that extreme temperatures act as a non-specific stress increasing sympathetic tone which stimulates progesterone secretion and peripheral concentration. The response of the sheep to low temperature in terms of the decreased rectal temperatures and respiratory rates, with increases during the exposure to high temperatures, agree with similar observations reported by Hopkins et al. (1978). The plasma glucose concentrations observed here are comparable to the normal range for sheep (Schalm et al., 1975). The relatively stable body weights, heart 
rates and glucose concentrations demonstrate that the stresses imposed were not so severe as to stimulate non-specific physiological changes.

This research was made possible by a grant from the Australian Wool Research Fund (L/8/1114). We thank Dr Ron I. Cox, C.S.I.R.O. Division of Animal Production, for the gift of progesterone antiserum; Mr Moss, Greenslopes Hospital, Department of Medicine, for performing the ovarian catecholamine assays; and Mrs Barbara Beasley and Mr Saad Gatie for valuable assistance.

\section{References}

Ashworth, C.J., Sales, D.I. \& Wilmut, I. (1984) Patterns of progesterone secretion and embryonic survival during repeated pregnancies in Damline ewes. Proc. 10th Int. Congr. Anim. Reprod. \& A.I., Urbana 2, 74-76, A6SN.

Baird, D.T. \& Land, R.B. (1973) Division of the uterine vein and the function of the adjacent ovary in the ewe. J. Reprod. Fert. 33, 393-397.

Baird, D.T., Land, R.B., Scaramuzzi, R.J. \& Wheeler, A.G. (1976) Functional assessment of the autotransplanted uterus and ovary in the ewe. Proc. R. Soc. B 192, 462-474.

Cannon, W.B. \& Rosenblueth, A. (1949) The Supersensitivity of Denervated Structures: a Law of Denervation. Macmillan, New York.

Collier, H.O.J., Francis, D.L. \& Schneider, C. (1972) Modification of morphine withdrawal by drugs interacting with humoral mechanisms: some contradictions and their interpretation. Nature, Lond. 237, 220-223.

Condon, W.A. \& Black, D.L. (1976) Catecholamineinduced stimulation of progesterone by the bovine corpus luteum in vitro. Biol. Reprod. 15, 573-578.

de la Torre, J.C. \& Surgeon, J.W. (1976) A methodological approach to rapid and sensitive monoamine histofluorescence using a modified glyoxylic acid technique: the SPG method. Histochemistry 49, 81-93.

Dighe, K.K. \& Hunter, W.M. (1974) A solid phase radioimmunoassay for plasma progesterone. Biochem. J. 143, 219-231.

Filogamo, G. \& Muti, R. (1968) A propos d'une technique de denervation du canal alimentaire au moyen du froid. C. r. Séanc. Ass. Anat. 141, 873-879.

Flint, A.P.F., Anderson, A.B.M. \& Turnbull, A.C. (1974) Control of utero-ovarian and peripheral venous plasma progesterone by $\beta$-sympathomimetic drugs in pregnant sheep. J. Endocr. 63, 253-254.

Gibson, W.R., Roche, P.J., Summers, R.J. \& Wylie, S.N. (1984) Time course of sympathetic denervation of the rat ovary after freezing its nerve supply. $J$. Reprod. Fert. 72, 429-433.

Goding, J.R., Baird, D.T., Cumming, I.A. \& McCracken, J.A. (1971) Functional assessment of autotransplanted endocrine organs. Acta endocr., Copenh., Suppl. 158, 169-191.

Godkin, J.D., Black, D.L. \& Duby, R.T. (1977) Stimulation of cyclic AMP and progesterone synthesis by
$\mathrm{LH}, \mathrm{PGE}_{2}$ and isoproterenol in the bovine $\mathrm{CL}$ in vitro. Biol. Reprod. 17, 514-518.

Hopkins, P.S., Knights, G.I. \& Le Feuvre, A.S. (1978) Studies of the environmental physiology of tropical merinos. Aust. J. agric. Res. 29, 161-171.

Jacobowitz, D. \& Laties, A.M. (1970) Adrenergic reinnervation of the cat ovary transplanted to the anterior chamber of the eye. Endocrinology 86, 921-924.

Jordan, A.W., Caffrey, J.L. \& Niswender, G.D. (1978) Catecholamine-induced stimulation of progesterone and adenosine $3^{\prime}, 5^{\prime}$-monophosphate production by dispersed ovine luteal cells. Endocrinology 103, 385-392.

Kostrzewa, R.M. \& Jacobowitz, D.M. (1974) Pharmacological actions of 6-hydroxydopamine. Pharmac. Rev. 26, 199-288.

Kupfer, M. (1978) The sexual cycle of female domesticated mammals. Union of South Africa Dept. Agric. 13th \& 14th Rep. Direct. Vet. Education \& Res, Onderstepoort, Pretoria, pp. 1209-1270.

Lamond, D.R., Gaddy, R.G. \& Kennedy, S.W. (1972) Influence of season and nutrition on luteal plasma progesterone in Rambouillet ewes. J. Anim. Sci. 34, $626-629$.

Mead, J. \& Bonmarito, C.L. (1949) Reliability of rectal temperatures as an index of internal body temperature. J. appl. Physiol. 2, 97-109.

Neilson, D., Jones, G.S., Woodruff, J.D. \& Goldberg, B. (1970) The innervation of the ovary. Obstet. Gynec. Surv. 25, 889-904.

Powell, C. (1976) Breeding patterns in the Australian Sheep Industry. In The Australian Sheep Industry Survey, 1970-71 to 1972-73, pp. 76-82. Bureau of Agricultural Economics, Canberra.

Quirke, J.F., Hanrahan, J.P. \& Gosling, J.P. (1979) Plasma progesterone levels throughout the oestrous cycle and release of $\mathrm{LH}$ at oestrus in sheep with different ovulation rates. J. Reprod. Fert. 85, 37-44.

Rao, L.V. \& Pandy, R.S. (1982) Seasonal changes in plasma progesterone concentrations in buffalo cows (Bubalus bubalis). J. Reprod. Fert. 66, 57-61.

Rhind, S.M., Robinson, J.J., Fraser, C. \& Phillippo, M. (1977) Effects of season and lactation on ovulation rate, plasma progesterone concentrations in early pregnancy and lamb production in Finnish Landrace $\times$ Dorset Horn ewes. Anim. Prod. 24, 128, Abstr. 
Rhind, S.M., Chesworth, J.M. \& Robinson, J.J. (1978) A seasonal difference in ovine peripheral plasma prolactin and progesterone concentrations in early pregnancy and in the relationship between the two hormones. J. Reprod. Fert. 52, 79-81.

Rosenberg, M., Herz, Z., Davidson, M. \& Folman, Y. (1977) Seasonal variations in post-partum plasma progesterone levels and conception in primiparous and multiparous dairy cows. J. Reprod. Fert. 51, 363-367.

Rosenberg, M., Folman, Y., Herz, Z., Flamenbaum, I., Berman, A. \& Kaim, M. (1982) Effect of climatic conditions on peripheral concentrations of $\mathrm{LH}$, progesterone and oestradiol-17 $\beta$ in high milk-yielding cows. J. Reprod. Fert. 66, 139-146.

Schalm, O.W., Jain, N.C. \& Carrol, E.J. (1975) Veterinary Hematology, 3rd edn. Lea and Febiger, Philadelphia.

Selye, H. (1950) The Physiology and Pathology of Exposure to Stress. Acta Incorporated, Montreal.

Snedecor, G.W. \& Cochran, W.G. (1967) Statistical Methods, 6th edn, pp. 135-139, Iowa State University Press, Ames.
Sokal, R.R. \& Rohlf, F.J. (1981) Biometry, 2nd edn. W.H. Freeman, San Francisco.

Stefenson, A., Owman, Ch., Sjöberg, N.-O., Sporrong, B. \& Walles, B. (1981) Comparative study of the autonomic innervation of the mammalian ovary, with particular regard to the follicular system. Cell Tiss. Res. 215, 47-62.

Stott, G.H. \& Wiersma, F. (1973) Climatic thermal stress, a cause of hormonal depression and low fertility in bovine. Int. J. Biometeor. 17, 115-122.

Von Euler, U.S. \& Lishajko, F. (1961) Improved technique for the fluorimetric estimation of catecholamines. Acta physiol. scand. 51, 348-356.

Wheeler, A.G. \& Barnes, A. (1983) Variation in peripheral progesterone concentrations with environmental temperature in ewes on Days 7 and 11 of the oestrous cycle. J. Reprod. Fert. 69, 697-701.

Wheeler, A.G. \& Land, R.B. (1977) Seasonal variation in oestrus and ovarian activity of Finnish Landrace, Tasmanian Merino and Scottish Blackface ewes. Anim. Prod. 24, 363-376.

Received 6 December 1985 